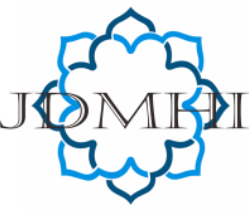

email: jdmhi@walisongo.ac.id

Journal of Digital Marketing and Halal Industry

ISSN: $2716-4810$ (print) ISSN: 2716-4802 (online)

\title{
A Strategy Framwork For Deciding Between Alliances Or Acquisition Of Johnson \& Johnson Pharmaceutical Company (Case Study: Strategy Farmwork of Johnson \& Johnson And Cipla Inc in The Production of Anti Infectious Drugs)
}

\section{Nur Aini Fitriya Ardiani Aniqoh}

Faculty of Islamic Economics and Business, State Islamic University Walisongo Semarang, Indonesia

\section{A R T I C L E I N F O}

\section{Article history:}

Received 04 Desember 2019

Received in revised form 14 Januari 2020

Accepted 14 Januari 2020

Keywords:

Strategy Framwork, Alliance and

Acquisition, Anti-Infectious Drugs.

\begin{abstract}
A B S T R A C T
This study analyzes a strategy framwork for deciding between alliances or acquisition of Johnson \& Johnson Pharmeutical Company. The general objective of this study is to determine the appropriate corporate development strategy of Johnson \& Johnson to strengthening the position in the area of infectious diseasese to help the mankind to get the best anti infectious drugs with the affordable price. Infectious diseases is a second leading killer worldwide, it is consist of HIV/ AIDS, TB, Hepatitis C, etc. Infectious diseases have caused an unprecedented global health crisis. The Asia division of Johnson \& Johnson plans to invest in open innovation through more research partnerships and collaborative efforts that connect the medical and academic communities to its $R \& D$ centers especially in infectious disease. The data used in this research is data result of observation, literature study and interviews with senior executives and consultants who handle comparable decision of Johnson\&Johnson. The data show that alliance is preferrable. High uncertainty within the environment is the most influencing factor to determine this choice. Due to the industry nature, many $R \& D$ collaborations in developing particular drugs are established. By defining the proper governance structure the collaboration can limit the risk of losing in the learning race and core competencies spillover while obtaining the knowledge access to the counterparty. The Strategic alliance between Johnson \& Johnson and Cipla Inc can help them toughen the corporate development strategy. Because of their similarities in the production of anti-infectious drugs, they can cooperate to penetrate emerging markets and do several $R \& D$ collaborations to create a competitive advantage.
\end{abstract}

* Corresponding author. email: nuraini_faa@yahoo.com http://dx.doi.org/10.21580/jdmhi.2019.1.1.4730 


\section{Introduction}

A business strategy is an important thing that needs to be done from the start. Business strategy is the company's efforts to take policies and guidelines that have commitments and integrated actions and are designed to build excellence in business competition to meet and achieve business goals. In business development, alliances and acquisitions are an important technique. Since the 1990s the alliance is a technique choice that is quite effective in business, where each element is able to work together in developing a project or business.

This study focus on a strategy framwork for deciding between alliance or acquisition of Johnson\&Johnson Pharmaceutical Company. Johnson\&Johnson is the largest pharmaceutical company in 2019 according to Fortune 500. Based on Johnson\& Johnson company structure, it has three major segments of consumer health care, medical devices and diagnostics and pharmaceutical which offer the world's broadest range of health care products.

Johnson\&Johnson's vision is to be a source of innovation for emerging markets and address the unique needs of Asia Pacific patients. Company's current strategy is achieving growth through differentiated medicines, transformational pipeline and global product launches. Johnson\& Johnson has also entered into pharmaceutical research partnerships that connect biotech, medical, and academic communities to its global research centers.

Johnson \& Johnson's pharmaceutical is considered to be promising partner especially in infectious disease. Infectious disease is a disease caused by the entry of germs. This disease is transmitted from one person to another. The main causes of infection include bacteria and living organisms (organisms). These germs spread in various ways and vectors. Infectious diseases is a second leading killer worldwide, it is consist of HIV/ AIDS, TB, Hepatitis C, etc

The Asia division of Johnson \& Johnson plans to invest in open innovation through more research partnerships and collaborative efforts that connect the medical and academic communities to its $R \& D$ centers especially in the production of anti infectious drugs. Therefore, the best strategic partnership of Johnson and Johnson through alliance or acquisition because of high fit and high synergies.

Based on the data above, this research will be focus to determine and analyze the best strategy framwork for deciding between alliance or acquisition of Johnson\&Johnson Pharmaceutical company with the specific case study on strategy farmwork of Johnson $\&$ Johnson and Cipla Inc in the production of anti-infectious drugs. This study is very important because with the proper collaboration between the two companies it can make a major contribution to the world of health, especially for infectious diseases, so that, patients who are detected by the disease can get good anti-infective drugs at affordable prices. 


\section{Literature Review}

\section{The concept of Halal Value Chain}

\section{Alliance}

A company's experience in managing acquisitions or alliances is bound to influence its choices. Some businesses have developed abilities to manage acquisitions or alliances over the years and regard them as core competencies. They've created special teams to act as repositories of knowledge and institutionalized processes to identify targets, bid or negotiate with them, handle due diligence, and tackle issues that arise after a deal is made. They've learned the dos and don'ts from experience and created templates that help executives manage specific acquisition- or alliance-related tasks. In addition, they've developed formal and informal training programs that sharpen managers' deal-related skills. (Jeffrey $\mathrm{H}$. Dyer.2004)

Some analysts may say that strategic alliances are a recent phenomena in our time, in fact collaborations between enterprises are as old as the existence of such enterprises. Examples would be early credit institutions or trade associations like the early Dutch guilds. There have always been strategic alliances, but in the last couple of decades the focus and reasons for strategic alliances has evolved very quickly. (Cumming. 2009)

The success of any alliance depends on how effective the capabilities of the involved enterprises are matched and whether the full commitment of each partner to the alliance is achieved. There is no partnership without trade-offs, but the benefits of it must preponderate the disadvantages, because alliances are made to fill gaps in each others 'capabilities and capacities. Some key factors that have to be considered to be able to manage a successful alliance include. (Margharita,2010)

- Understanding: The cooperating companies need a clear understanding of the potential partner's resources and interests and this understanding should be the base of set the alliance goals.

- No time pressure: During negotiations time pressure must not have an influence on the outcome of the process. Managers need time to establish a working relationship with each other, develop a time plan, set milestones, and design communication channels.

- Limited alliances: Some incompatibilities between enterprises might not be avoidable, so the number of alliances should be limited to a necessary amount, which enables the companies to achieve their goals.

- Good connection: Negotiations need experienced managers. The managers from large firms need to be connected very well so they have the possibility to integrate different departments and business areas over internal borders, and they need legitimations and support from the top management.

- Creation of trust and goodwill: The best basis for a profit-yielding cooperation between enterprises is the creation of trust and goodwill, because it increases tolerance, intensity and openness of communication and makes the common work easier. Further it leads to equal and satisfied partners.

- Intense relationship: Intensifying the partnership leads to the fact that 
partners get to know each other better, each other's interests and operating styles and increases trust.

\section{Acquisition}

Corporate acquisitions are a common and a popular form of corporate development. With an overall yearly value of hundreds of billions of dollars and numbering in tens of thousands (Cartwright \& Schoenberg, 2006) acquisitions are also the most important form of foreign direct investment (Brackman, Garretsen, \& van Marrewijk, 2006; Schjelderup, 2001), with about $75 \%$ of FDI being in the form of acquisitions (UNCTAD, 2000). Even if acquisitions are very common, research results on their effect on company profitability and performance are mixed, and there is no clear wisdom on wealth transfers between the acquiring and target company shareholders. (Bruner, 2004b; Cartwright et al., 2006; Moeller, Schlingemann, \& Stultz, 2005).

\section{Competitive Advantage}

Besides of Alliace and Acquisition, the final destination of the company is reaching competitive advantage. Competitive advantage refers to the comparative positional superiority in the marketplace that leads a firm to outperform its rivals (Porter, 1985). Competitive advantage has been defined in many different ways. According to Schendel (1978, p.25), competitive advantage is the unique position an organisation works hard to develop through its competitors. Competitive advantage is the ability of an organization to create a strong position over its competitors" (Li, Ragu-Nathan, RaguNathan, and Rao, 2006, p.111).
There are three determinants to create a competitive advantage:

1. Benefit. It is refers to something that the customers truly need. It offer real value, product's features, advantages, and the benefit for customers.

2. Target market. The customer of the product, the company should now what the customer need to become their life better. That's how the company create demand, the driver of all economic growth.

3. Competition. Identification of real competitors. It is include anything else the customer could do to meet the need we can fulfill.

\section{Method, Data, and Analysis}

This research uses a qualitative method approach. The data sources used in this study are primary and secondary data. The data primer used in this research is observation and interviews with senior executives and consultants who handle comparable decision of Johnson\&Johnson. While the secondary data from literature review of Johnson\& Johnson and Cipla Inc.

\section{Result and Discussion}

\section{Strategic Goals of Johnson \& Johnson for the} Coming 5 to 10 Years

We established a SWOT analysis to discover opportunities for the upcoming 5 to 10 years. 
Appendix 1 SWOT Analysis Johnson \& Johnson

\begin{tabular}{|c|c|c|c|}
\hline Strengths & Weaknesses & Opportunities & Threats \\
\hline $\begin{array}{l}\text { A Substantial Marketing Arsenal } \\
\quad \text { Johnson \& Johnson can call } \\
\text { upon a network of subsidiaries } \\
\text { armed with significant sales and } \\
\text { marketing prowess, as well as } \\
\text { expertise in a number of therapy } \\
\text { areas. The company possesses a } \\
\text { global sales force which serves to } \\
\text { attract joint venture possibilities. } \\
\text { Strategic Acquisitions } \\
\text { J\&J has maintained a stable } \\
\text { financial position by utilizing cash } \\
\text { reserves to finance timely corporate } \\
\text { acquisitions. Its Triple A Credit } \\
\text { Rating represents that a company } \\
\text { able to take advantage of } \\
\text { opportunities that arise without } \\
\text { being limited by burdensome levels } \\
\text { of debt. } \\
\quad \text { The potential of an } \\
\text { Product Diversification } \\
\text { The J\&J pharmaceutical portfolio, } \\
\text { launches and the promise of } \\
\text { achieving forecast sales lead to an } \\
\text { increase of revenue growth } \\
\text { estimation. } \\
\text { and its large Medical Devices \& } \\
\text { Diagnostics and Consumer Health } \\
\text { divions serves to reduce } \\
\text { Thendence upon any one area. } \\
\text { range of choice when pursuing } \\
\text { opportunities with the greatest } \\
\text { growth prospects. } \\
\text { Positive Revenue Growth } \\
\text { Proiections }\end{array}$ & \begin{tabular}{l} 
Dependence on the \\
$\underline{\text { Success of Launch }}$ \\
Products \\
Many new \\
launch products are \\
vulnerable to the \\
uncertainty of \\
regulatory review and \\
ultimate market \\
benefits may vary \\
substantially from \\
forecast, therefore, a \\
reliance upon launch \\
products potentially \\
represents a threat to \\
J\&J's outlook. \\
Reliance on Small \\
Molecular Drugs \\
\multicolumn{1}{c}{ Compared to } \\
biologics, small \\
molecules are notably \\
more impacted by \\
generic competition. \\
As such, although the \\
J\&J is engaged in \\
producing new small \\
molecule products, \\
when coming off- \\
patent, declines are \\
still forecast.
\end{tabular} & $\begin{array}{l}\text { Wide Range of Potential } \\
\text { Cross-selling } \\
\text { Opportunities } \\
\quad \text { J\&J is in a position } \\
\text { to strategically develop a } \\
\text { myriad of cross selling } \\
\text { opportunities. } \\
\text { Maximizing its balance } \\
\text { between Pharmaceuticals, } \\
\text { Diagnostics, and Medical } \\
\text { Devices could result in } \\
\text { increased revenues. } \\
\text { Potential to Exploit } \\
\text { Biologics Market } \\
\text { The additional of further } \\
\text { biologics to its portfolio } \\
\text { can serve as a buffer as } \\
\text { small molecule patents } \\
\text { expiries. } \\
\text { Further market } \\
\underline{\text { expansion to developing }} \\
\text { countries } \\
\text { For infectious diseases, } \\
\text { developing countries still } \\
\text { need cheap drugs to fulfill } \\
\text { consumers needs of } \\
\text { affordable medicine. It is } \\
\text { a big project to develop } \\
\text { and potentially could } \\
\text { broaden it alliance } \\
\text { network. }\end{array}$ & $\begin{array}{l}\text { Negative Impact of } \\
\text { Recent Product } \\
\text { Recalls } \\
\text { J\&J has the } \\
\text { misfortune of } \\
\text { having to recall of } \\
\text { more than } 40 \\
\text { medicines recently, } \\
\text { FDA inspectors } \\
\text { required the } \\
\text { company to recall } \\
\text { the children's } \\
\text { medications after } \\
\text { discovering the } \\
\text { company had not } \\
\text { looked into dozens } \\
\text { of consumer } \\
\text { complaints about } \\
\text { "black or dark } \\
\text { specks" in Tylenol } \\
\text { and other products. } \\
\text { The company } \\
\text { stands to take a hit } \\
\text { to its sterling } \\
\text { reputation as } \\
\text { congressional } \\
\text { lawmakers are } \\
\text { blasting the } \\
\text { company's } \\
\text { competence and } \\
\text { integrity. }\end{array}$ \\
\hline
\end{tabular}


There are two most strategic goals of Johnson\&Johnson

\section{Strengthening the Position in the Area of Infectious Diseases}

Infectious diseases is a second leading killer worldwide, it is consist of HIV/ AIDS, TB, Hepatitis C, etc. Infectious diseases have caused an unprecedented global health crisis, accounting for more than 5 million deaths each year, with the majority of these in developing countries, particularly subSaharan Africa (World Health Organization report, 2002).

The Janssen Pharmaceutical Companies of Johnson \& Johnson are dedicated to addressing and solving the most important unmet medical needs of time, including infectious disease (e.g. HIV/AIDS, Hepatitis $\mathrm{C}$ and tuberculosis). There are many market products for infectious disease, such as in the appendix below:

Appendix 2 Infectious Diseases and its medicine

\begin{tabular}{ll}
\hline \multicolumn{1}{c}{ Infectious Diseases } & \multicolumn{1}{c}{ Medicines } \\
\hline HIV/AIDS & $\begin{array}{l}\text { Prezista, } \\
\text { Edurant,Intelence, } \\
\text { Doribex, TMC 278 } \\
\text { TMC 207, TMC 407 } \\
\text { Tuberculosis }\end{array}$ \\
Hepatitis C & TMC 435, Telepriver \\
Malaria, tuberculosis, & $\begin{array}{l}\text { Crucell vaccines in } \\
\text { Ebola and HIV }\end{array}$ \\
\hline
\end{tabular}

Filings/approvals assumed to be in US and EU unless otherwise noted. This information is accurate as of the date hereof to the best of the Company's knowledge. Johnson \& Johnson assumes no obligation to update this information (johnson\&johnson.2017).
The FDA has granted accelerated approval for Johnson \& Johnson's anti-HIV protease inhibitor Prezista (darunavir, previously known as TMC114) co-administered with ritonavir for use in combination therapy in treatment-experienced patients who have failed other antiretroviral therapies (hospitalpharma, 2010). Prezista is building to market leadership because it was approved in 101 countries in the world. The tough competitor of Prezista is Aptivus from Boehringer Ingelheim Pharmaceutical company.

Basically, what makes a product differentiation difficult is the fact that both drugs have a novel resistance profile that will be of great value, and that both have been indicated for use in salvage therapy. In addition, the two drugs remain difficult to compare since they have been tested on different patient populations, with trial participants having quite different levels of treatment experience and resistance profiles.

However, pricing has been a major concern, with Aptivus and Roche and Trimeris' Fuzeon (enfuvirtide) - the only currently approved entry inhibitor - ranking among the top five most expensive HIV drugs on the market (hospitalpharma.2010). In contrast, The Fair Price Coalition Group, has welcomed the low pricing set by Johnson \& Johnson for Prezista, giving the drug positive PR from an unexpected angle and thus possibly easing acceptance among HIV patients.

On the other hand, within the pharmaceutical industry there are only a small number of companies that produce quality-assured Tuberculosis drugs, such as TMC 207 from Tibotec and the TB (Tuberculosis) alliance. TMC207 has been 
successfully applied in a phase II efficacy study because TMC207 has promise for not only reducing treatment burden, but also providing a powerful tool against $\mathrm{TB}$ that is resistant to current TB drugs.

The main problems preventing scale-up of Tuberculosis treatment is because for some medicines there is only one source for the active ingredient needed for drug production. There is little commercial interest within the pharmaceutical industry to develop and sell MDR-TB drugs because investment in research has been widely inadequate due to the perception that $\mathrm{TB}$ is a poor people's disease. . Therefore, the lack of competition among drug makers has led to high drug prices, which have made access to multidrugresistant tuberculosis (MDR-TB) treatment difficult and very costly.

Moreover, Hepatitis C (HCV) is other infectious disease, the successful drugs for the disease is Telaprevir (VX-950), marketed as the brand name INCIVEX, the world's second-biggest seller of health products. The drug for the treatment of hepatitis is codeveloped by Vertex and Johnson \& Johnson. On May 23rd 2011, US FDA approved Telaprevir for the treatment of people with chronic genotype 1 hepatitis $\mathrm{C}$ with compensated liver disease.

The biggest competitor of Incivex is Victrelis from Mercks Pharmaceutical company, also known as Boceprevir, which became the first hepatitis $\mathrm{C}$ drug in almost a decade to win FDA approval. Victrelis effectively cured more than 60 percent of patients in clinical trials when used along with existing drugs.
Incivex's drug, along with a competitor from Merck, has created new demand for treatment among the estimated 3 million Americans with hepatitis $\mathrm{C}$ infections. Incivex becomes the only newly approved drug to reach blockbuster sales $(\$ 1000$ million) in the first year of marketing and Victrelis is projected to have sales of $\$ 150$ million in 2011 (krishan-maghon, 2011).

\section{Expanding Market to Developing Countries}

Developing countries are prosperous market for Johnson\&Johnson. For example for Asia. This continent has a lot of developing countries. In June, 2009, J\&J established R\&D center in Shanghai. The center will ensure that Asia becomes a crucial part of its portfolio development in all its strategic therapeutic areas, include neuroscience, cardiovascular and metabolic disease, immunology, oncology and virology. A special focus will be placed on diseases with specific, high unmet needs in the region. These include oncology, infectious and metabolic diseases. The Asia division plans to invest in open innovation through more research partnerships and collaborative efforts that connect the medical and academic communities to its R\&D centers. For the future 10 years, the expansion strategy is still need to developed and improved. In the appendix 3 (below) show the journey of Johnson and Johnson Collaboration/Agreement/Acquires in the drugs of infectious diseases ( AIDS, Tuberculosis, Hepatitis C ) from 2002 till 2018. 


\section{Appendix 3 Johnson \& Johnson Collaboration/Agreement /Acquires In The Drugs of Infectious Diseases (AIDS, Tuberculosis, Hepatitis B and Hepatitis C)}

\begin{tabular}{cl}
\hline Years & Collaboration/Agreements/ Acquires \\
\hline 2002 & Johnson \& Johnson acquires Tibotec- \\
& Virco BVBA \\
2004 & Johnson \& Johnson collaboration in the \\
& microbicides \\
& field in 2004, with the International \\
& Partnership \\
& for Microbicides (IPM). \\
June 2004 & $\begin{array}{l}\text { Janssen Pharmaceutica, a Johnson \& } \\
\text { Johnson company signed an agreement } \\
\text { with Vertex Osaka-based Mitsubishi } \\
\text { Tanabe Pharma. }\end{array}$
\end{tabular}

April 2007 Johnson \& Johnson signed its first license agreement with Aspen Pharmacare of South Africa to provide PREZISTA® in SSA and LDCs at a special access price

December Johnson \&Johnson entered into a $2008 \quad$ license agreement with Emcure Pharmaceuticals Limited of India

June 2009 Johnson \& Johnson announced a landmark collaboration with the Global Alliance for TB Drug Development (TB Alliance)

July 2009 Johnson \& Johnson entered into a license and collaboration agreement with Gilead Sciences, Inc

Johnson and Johnson signed a licensing agreement with Aspen for

\section{Explanation}

To help address the vast unmet needs of patients with HIV/AIDS and other infectious diseases such as tuberculosis.

The Program provided IPM with a royalty-free license for TMC120 (dapivirine)to develop, manufacture and distribute the compound as a vaginal microbicide in resourcepoor countries.

To develop and commercialize INCIVEKTM (telaprevir). Vertex has rights to commercialize INCIVEK in North America. Tibotec has rights to commercialize INCIVEK in Europe, South America, Australia, the Middle East and certain other countries. The agreement also includes a royalty on product sales in Europe and other territories outside of North America and the Far East.

The agreement included initial operational terms to register, package and distribute the $300 \mathrm{mg}$ formulation

To distribute and manufacture darunavir formulations in India under local trade name Virem

To share expertise and resources in the development of TMC207 potentially the first TB compound with a new mechanism of action in 40 years - and to work together in the discovery of additional new drugs for TB(Tuberculosis)

For the development and commercialization of a new, once-daily, FDC containing EDURANT ${ }^{\mathrm{TM}}$ and Gilead's Truvada ${ }^{\circledR}$ (emtricitabine and tenofovir disoproxil fumarate).

The initial terms included the registration and distribution of the $100 \mathrm{mg}$ formulation for HIV 
INTELENCE® (etravirine) in SSA

$2011 \quad$ Johnson \& Johnson entered into agreements with multiple generic manufacturers: Emcure

Pharmaceuticals, Hetero Drugs Limited, Matrix Laboratories Limited (a Mylan Company),

Strides Arcolab and Aspen Pharmacare to register, manufacture, market and distribute a $25 \mathrm{mg}$ generic version of rilpivirine, in SSA, LDCs and India as a single agent medicine and a fixed-dose combination (FDC) product with $300 \mathrm{mg}$ tenofovir disoproxil fumarate and 300 mg lamivudine

2014 Johnson \& Johnson acquired Alios BioPharma, Inc.

2015 Johnson and Johnson announced a definitive agreement to acquire Novira Therapeutics, Inc.

2018 Johnson \& Jonhson has entered into an agreement with Arrowhead Pharmaceuticals, Inc treatment-experienced adult patients at a special access price.

Four of these agreements were signed before any regulatory approval in the U.S. or Europe,allowing generic manufacturers to more quickly develop formulations and seek regulatory approvals of generic rilpivirine

The company acquired Alios BioPharma, Inc. for $\$ 1.75$ billion. As a result of the purchase, Alios was incorporated into the infectious diseases therapeutic area of the Janssen Pharmaceutical Companies of Johnson \& Johnson

A privately held, clinical-stage biopharmaceutical company developing novel therapies for curative treatment of chronic hepatitis B virus (HBV) infection. The acquisition includes Novira's portfolio of novel antivirals, including its lead candidate, NVR 3-778.

The cooperation for an exclusive, worldwide license to develop and commercialize AROHBV, a Phase 1/2 subcutaneous, ribonucleic acid interference (RNAi) therapy candidate being investigated for the treatment of chronic hepatitis B viral infection.

\section{Ally or Acquire? - An Approach to} Determine the Corporate Development Mode

Before arrived at the proper corporate development mode for those two above strategic goals, we need to evaluate J\&J key resources and capabilities and analyze the environment.

\section{Johnson\&Johnson's Key Resources and Core Capabilities}


As one of the top five largest global pharmaceutical companies, J\&J has a high financial endowment with 8.7 percent profit growth of USD 81.58 billion in 2018 with net income USD 15.29 billion a $6.71 \%$ increase from 2017. The pharmaceutical business itself generated 45 percent of the company's total revenue with USD $\$ 76.5$ billion sales in 2017. With the good financial performance, the future operational growth will increase as new product contributed to growth and core brands delivered solid performance. They engage in several big partnership projects to develop their alliance capabilities. Their social and institutional capital is strong since J\&J's broad social network of partnership with various companies and other institutions which has different cultural and structural dimensions. Additionally, in 2001, J\&J has builded up their alliance management with series of trial and error. After eight to nine years learning experiences, nowadays they have a strong alliance management worldwide to strengthen their geographic presence.

\section{The Environmental Context}

In order to determine the appropriate corporate development mode, the framework developed by Hoffman and Schaper Rinkel (2001) is implemented:

- Uncertainty: Pharmaceutical industry contains high inherent risk by itself. The drug research could take 10 to 15 years before getting FDA approval (ABRC, 2017). According PhRMA (2018) only 5 out of 5000 experiments made through the final approval stage costing on average $\$ 1.2$ billion each. Regulation changes as exemplified by just recently approved US health reform in 2010 increase the uncertainty. Various IPR standard and infringement by competitors worsen the uncertainty as exemplified by litigation cases faced by J\&J with its PREZISTA infringement by generic manufacturer namely Lupin and Mylan (J\&J, 2011). Hence the uncertainty level is categorized as high.

- Urgency: Infectious diseases such as Hepatitis C and AIDS are invented in 1989 and 1981 respectively contains much room for growth (Stop-Hepatitis, 2011). WHO (2018) argued almost onethird of world's population is infected with TB bacili. More than 65\% TB infection is concentrated in emerging countries, so do with Hepatitis C and AIDS. Thus solutions for these problems are urgently needed. However relatively current approvals of several pipelines such as EDURANT and INCIVO and TMC435 entered phase III clinical trials (J\&J Pipeline, 2011) ease the urgency. Generally the urgency is moderate as some of the growth had been capitalized by $\mathrm{J} \& \mathrm{~J}$ in terms of patent approval.

- Dispersion of Knowledge: Pharmaceutical industry is characterized by high $R \& D$ activities reaching up to $\$ 165$ billion in 2017, average $R \& D$ spending moderately increased to 20.9\%. (Prescouters, 2019). Also, infectious disease viruses can be resistant to existing drugs (Avert, 2017) thus new drugs development never stops. As infectious disease is a broad area, the dispersion of knowledge level itself is abundant since many 
collaborations are required to cover the area.

- Competition: Competition mainly comes from generic manufacturer as many counterfeit products and IPR infringement appear (J\&J, 2018). High growth in emerging markets agglomerates competition there making it highly intense. The health reform in US regarding price rebates also tighten the competition demanding high efficiency of firms. Conclusively the competition is high for $\mathrm{J} \& \mathrm{~J}$.

- Behavioral Uncertainty: $R \& D$ is the most critical value chain in pharmaceutical firm as firms spend highly on it. The protection of IPR alone is not sufficient, this decreases efficiency due to high governance cost (Hoffman and Schaper-Rinkel, 2001). The expensive drug development creates incentive for other to behave opportunistically to mitigate the expensive $R \& D$ cost.

- Persistence of Economic Synergies: Most of the drug development occur in very specific area such as J\&J and Gilead with its FDC combination in HIV therapy. The trends in the collaboration show short-term, complementary and specific orientation for the parties involved. Therefore we can argue that there is low persistence of economic synergy.

- Resource Endowment \& Social capital: $J \& J$ is one of the largest companies in health care business thus their financial strength is large. As indicated in the appendix, J\&J had been doing many collaborations with several partners even some acquisitions. In an article in
Bloomberg (2011) analysts argue that J\&J indeed possess high absorptive capacity and "eagle eye" in mapping potential drugs in development phase. Its long establishment and its broadbased businesses implicitly says that J\&J possess high social capital.

\section{Discussion}

To find out and analyze the implications of spiritual intelligence and organizational citizenship behavior on employee performance, then used path analysis. Following are the results of regression analysis between variables Based on table 4, the regression equation $\mathrm{Y}_{1}=2.005+0.503 \mathrm{X}$ is obtained. This equation means that assuming a constant value of 2.005 , then if spiritual intelligence $(\mathrm{X})$ increases one unit, then organizational citizenship behavior $\left(\mathrm{Y}_{1}\right)$ will increase by 0.503 or it can be said that organizational citizenship behavior will change by 0.503 every one unit of spiritual intelligence.

\section{Recommendation: Main Focus on Alliances}

Based on the analysis above we arrive to conclusion that alliance is preferrable. High uncertainty within the environment perhaps is the most influencing factor to determine this choice. Also, quite high level of urgency to tap in external growth require quicker mode of entry to the focus area which prefer alliance over acquisitions (Hoffman and Schlosser, 2000). Due to its commitment to be a broad-based healthcare business J\&J needs to be present by forming alliances. However, high knowledge dispersion level exist thus it is impossible to acquire firms in all area. Grant and Baden Fuller (2004) stated that alliances fit better in situation of broad knowledge types and specialization by different firms in different areas. The 
efficiency aspects pointsthat most collaborations occurr on very specific area and intention to opportunistic behavior is salient in the industry. Lastly as J\&J has high social capital due to its long existence, alliance is preferred. Although J\&J is high in financial capital and high level of competition exists in the industry, alliances are the best mode of development considering other aspects in the framework, especially due to very high level of uncertainty.

As there is urgency to penetrate the emerging market where uncertainty is even higher and knowledge of particular market is still relatively low, less riskier mode of entry is more proper. The issue of low IPR in emerging market remains issue to solve. The entrance to emerging market which necessitates sequential synergy i.e distribution or manufacturing of products narrow the scope of activities to be cooperated. Therefore alliance type that protect the property-based knowledge in emerging market is favorable. "To serve unmet critical medical needs" is the slogan of J\&J. This implies that new drugs development is occurring on continuing basis. Due to the industry nature, many $R \& D$ collaborations in developing particular drugs are established. By defining the proper governance structure the collaboration can limit the risk of losing in the learning race and core competencies spillover while obtaining the knowledge access to the counterparty.

\section{Partner Search - Implications from Johnson\&Johnson's Resource Gaps and Needs}

After identifying alliance as the appropriate mode for J\&J to attain corporate goals, the next step is looking for appropriate partner. For this report, we try to develop the alliance based on the two goals with the main focus on expanding market to developing countries. The current situation of entering pharmaceutical research partnership gives a comprehensive explanation of resources and capabilities J\&J looks for from potential alliance partners.

\section{Potential Alliance Partners - Looking for the Fit}

To tap the opportunities existed, J\&J should pick the appropriate partner. We screen three potential partners and reach to Cipla Limited as the most potential partners such as in the appendix 4 .

\section{Appendix 4 Partner Screening}

\begin{tabular}{|l|l|l|l|l|}
\hline Company & Strategic Fit & Market Fit & Organization Fit & Cultural Fit \\
\hline Gilead & $\begin{array}{l}\text { Rapidly expanding product } \\
\text { portfolio, growing pipeline of } \\
\text { investigational drugs and } \\
\text { approximately 4,200 } \\
\text { employees in offices across } \\
\text { four continents. }\end{array}$ & $\begin{array}{l}\text { developing } \\
\text { ground-breaking } \\
\text { therapeutics to } \\
\text { treat life- } \\
\text { threatening } \\
\text { diseases. }\end{array}$ & $\begin{array}{l}\text { The structure } \\
\text { was designed to } \\
\text { support the } \\
\text { anticipated } \\
\text { growth of the } \\
\text { company and its } \\
\text { marketed } \\
\text { products }\end{array}$ & $\begin{array}{l}\text { High level of } \\
\text { corporate } \\
\text { responsibility }\end{array}$ \\
& & & \\
\hline
\end{tabular}




\begin{tabular}{|c|c|c|c|c|}
\hline Cipla Limited & $\begin{array}{l}\text { offers services like consulting, } \\
\text { commissioning, engineering, } \\
\text { project appraisal, quality } \\
\text { control, know-how transfer, } \\
\text { support, and plant supply. } \\
\text { Price reduction ability since } \\
\text { the focus is making a drugs } \\
\text { for low-level income society. } \\
\text { Pioneered a three-in-one } \\
\text { tablet called Triomune } \\
\text { containing a fixed-dose } \\
\text { combination (FDC) of three } \\
\text { ARVs (Lamivudine, } \\
\text { stavudine and Nevirapine } \\
\text { and also Duovir-N. (contains } \\
\text { Lamivudine, Zidovudine and } \\
\text { Nevirapine). } \\
\text { Manufactures generic } \\
\text { versions of many of the most } \\
\text { commonly prescribed anti- } \\
\text { retroviral medication in the } \\
\text { market and is a highly } \\
\text { capable manufacturer in its } \\
\text { own right. }\end{array}$ & $\begin{array}{l}\text { manufacturing } \\
\text { low-cost anti- } \\
\text { AIDS drugs for } \\
\text { HIV-positive } \\
\text { patients in } \\
\text { developing } \\
\text { countries makes } \\
\text { drugs to treat } \\
\text { cardiovascular } \\
\text { disease, arthritis, } \\
\text { diabetes, weight } \\
\text { control, } \\
\text { depression and } \\
\text { many other } \\
\text { health } \\
\text { conditions, and } \\
\text { its products are } \\
\text { distributed in } \\
\text { more than } 180 \\
\text { countries } \\
\text { worldwide }\end{array}$ & $\begin{array}{l}\text { The structure } \\
\text { was designed to } \\
\text { contribute to } \\
\text { fair and } \\
\text { transparent } \\
\text { working } \\
\text { environment }\end{array}$ & $\begin{array}{l}\text { All directors } \\
\text { and senior } \\
\text { management } \\
\text { employees } \\
\text { shall deal on } \\
\text { behalf of the } \\
\text { Company with } \\
\text { professionalis } \\
\text { m, honesty, } \\
\text { integrity as } \\
\text { well as high } \\
\text { moral and } \\
\text { ethical } \\
\text { standards. }\end{array}$ \\
\hline Roche & $\begin{array}{l}\text { focus on developing } \\
\text { medicines and diagnostics } \\
\text { that will help patients live } \\
\text { longer, better lives. }\end{array}$ & $\begin{array}{l}\text { strive to address } \\
\text { unmet medical } \\
\text { needs through } \\
\text { excellence in } \\
\text { science - from } \\
\text { early detection } \\
\text { and prevention } \\
\text { of diseases to } \\
\text { diagnosis, } \\
\text { treatment and } \\
\text { treatment } \\
\text { monitoring. }\end{array}$ & $\begin{array}{l}\text { Big and well } \\
\text { established } \\
\text { company with a } \\
\text { mature } \\
\text { organizational } \\
\text { structure. }\end{array}$ & $\begin{array}{l}\text { The culture } \\
\text { tends to boost } \\
\text { the learning } \\
\text { behavior of } \\
\text { employees } \\
\text { from any } \\
\text { incidents } \\
\text { happen. }\end{array}$ \\
\hline
\end{tabular}

Analysis of Cipla as follows:

Strategic Focus : High Fit

- Customer
Cipla company produce Daruvir (darunavir ethanolate tablets) and Nutrimune (antioxidant tablets). Those medicine are supportive therapy for HIV/AIDS, thus fit with Johnson \& Johnson's concern and 
might be attractive for Johnson \& Johnson. Based on annual report, on 2017-2018, Cipla exports to more than 170 countries worldwide and operates through low-risk, low-cost partnership arrangements. The large number of products in the registration pipeline will aid in increasing the Company's market share. (Appendix : Cipla growth in fixed assets)

\section{- Competitors}

Cipla has proposed to supply triple combination therapy for HIV/AIDS for $\$ 350$ per patient per year to Medicins San Frontieres. It has also offered to sell the therapy for $\$ 600$ per patient per year to poor governments, on the condition that the recipient governments provide the drugs for free to those with HIV/AIDS and since making the initial offer, it has dropped the price for some poor governments (cptech, 2011). Besides, Cipla's have strong competitors who also offered lower prices on generic medicine for AIDS which are Hetero and Ranbaxy (other Indian generic competitors).

\section{- Cost Structure}

Cipla will continue its Research \& Development division as future plan of action (Appendix: Research Deelopment in Cipla). Due the pharmaceutical industry is characterized by heavy $R \& D$ expenditure, thus Cipla needs partner with strong financial resources which will matched with Johnson \& Johnson for partners engaged in Research and Development.

- Capabilities

Cipla has core capabilities in production of anti-asthma, anti-HIV/AIDS and anti-cancer compounds which is fit with Johnson \&
Johnson aim in developing infectious disease division.

\section{Corporate Vision : High Fit}

Cipla's vision focuses on provide the health care infrastructure in developing countries, particularly Africa, the price of even the cheapest HIV/AIDS drug is still beyond the reach of the majority. Basic medical facilities and infrastructure are not available.

"We are aware that we have our own limitations and there is only so much that one company can do. We are glad that our humanitarian gesture on the price front has dramatically led to many companies, both Indian and international, offering anti-AIDS drugs at reduced prices." Said Dr Y K Hamied (Chairman and Managing Director). Due to Cipla and Johnson \& Johnson have same purpose in vision related with HIV/AIDS issue, both of Cipla and Johnson $\&$ Johnson have high fit in corporate vision.

\section{Corporate Culture: High Fit}

Cipla's corporate culture is bring health and care for people, thus innovation is key for create value such as creativity, resource (internal and external), employee, and ethical. Besides, in Johnson \& Johnson also have similar corporate culture that also want to bring health to people who needed and Johnson \& Johnson is a company who have big concern in innovation. In summary, Cipla and Johnson \& Johnson have high fit in corporate culture, thus those similarity will reduce conflict and gap between them.

\section{Organizational Task Needs : Low Fit}

Cipla faces challenge in patent because patent in pharmaceutical industry is still become problem in India because lack of awareness 
from governments in India. This is very different from what happened in Johnson \& Johnson who have high awareness for patent. In addition, India is under pressure to change its current patent laws to suit only multinational companies. Cipla and other like minded organisations are fighting this as best as possible (annual report of Cipla, 2018).

\section{Cipla - Is It the Best Choice?}

Cipla is now a big pharmaceutical company in India. Based on Pharmaceutical.com (2017), it is in the fourth ranks of the top five pharmaceutical company in India with its international sales at Rs. 47,319 crore during 2017. The company made a low-cost anti AIDS drugs and also other medicine including for TB and Hepatitis for developing countries patients. Roughly 40 percent of HIV/AIDS patients undergoing antiretroviral therapy worldwide take Cipla drugs. Considering the established criteria, Cipla can helps J\&J to achieve its goals.

\section{Establishing and Managing the Alliance - The Appropriate Governance Structure}

\section{Common Objective}

Alliances often ends up in a learning race among involved parties (Lei and Slocum, 1992). The intention to exploit the counterparties complementary assets maximally creates incentive to behave opportunistically within an alliance (Harrigan, 1985). Therefore, clear governance structure should be established to ensure the smoothness of the alliances with the basis of framework developed by Das and Teng (2000). The first step to do is to establish alliance specific goals and the governance structure in order to result in a win-win solution for both parties. Below are the proposed goals and proper structure of Johnson \& Johnson and Cipla alliance:

1. To develop an Single Tablet Regimen (STR) for AIDS

AIDS therapy involves the patient to consume combination of drugs (Avert, 2011). The current trend of Fixed Dose Combination (FDC) and Single Tablet Regimen (STR) which meld multiple drugs into 1 tablet is preferrable as it is more effective in suppressing the HIVvirus (Bangsberg et al, 2011). The current strong pipelines such as PREZISTA can be exploited heavily and combined with other medicine co-developed by Cipla to result in another STR after EDURANT-TRUVADA STR development with Gilead. Developing STR involves knowledge based propoerties from each firm. According to Das and Teng (2000), the best type of alliance in this condition is forming bilateral contract in form of partnership. Both parties could gain access to the technology of each firm in AIDS field and exchange information to reach this goal. High resource endowment of Johnson and Johnson can also help the collaboration to be successful as $R \& D$ activities only occuring cash outflows.

2. To strengthen the company's position in the area of Hepatitis C \& TB

The status of TMC 207 which is nearly approved by FDA and current approval of Telaprevir strengthen the portfolio of Johnson and Johnson. Cipla as the leader of pharmaceuticals company in India can give broader knowledge as they are also expert in Hepatitis-C and TB. Along with the high vision fit particularly in this area, $R \& D$ collaboration to develop new Hepatitis-C especially for other genotypes is highly awaited. As both firms have high knowledge 
resource in the field of Hepatitis $\mathrm{C}$ and $\mathrm{TB}$, the strength of both firm can be combined such as joint $R \& D$ and share of facility. In this kind knowledge $\mathrm{ft}$. knowledge alliances again bilateral contract is preferrable according to Das and Teng (2000) framework since knowledge spillover can be prevented by the proper formulation in the contract. Also the low protection of IPR in India exacerbate the risk of knowledge spillover.

\section{To penetrate the emerging market}

Johnson \& Johnson continued the strong progress in emerging markets by sales growing $14 \%$ operationally in Brazil, Russia, India and China (Johnson \& Johnson' hand book, 2010). Thus emerging market offers big opportunities to be exploited. However, there is high risk incorporating international expansion if conducted alone. In order to smoothen the process Johnson and Johnson can cooperate with Cipla to help them penetrate emerging market such as India, where Cipla is one the among the industry leaders. According to Verbeke (2009) Alliance with local partner reduce greatly the "distance" and liability of foreignness especially process of obtaining local knowledge. Cipla expertise in low cost manufacturing helps Johnson and Johnson to achieve greater efficiency to answer the demand in emerging market and mission to make AIDS drugs more affordable. The property based owned by Johnson and Johnson and the local knowledge of Cipla according to Das and Teng (2000) will be best to form equity joint venture. Johnson and Johnson will be at advantage position since the knowledge property owned by Cipla is more vulnerable to opportunistic behavior (Das and Teng, 2000). Reciprocal relationship occur here since Cipla also can advantage by J\&J strong financial strength.

\section{Alliance Structure}

The alliance's governance structure is detrimental to the alliance successfulness (Williamson, 1985; Li et al, 2008; Hennart, 1988). Moreover, Hamel (1991) argued that collaboration involving knowledge-based properties most likely raises learning race. Therefore a clear governance structure should be established within the alliance to minimize learning race and knowledge spillover. The framework by Das and Teng (2000) can help firms to carry out the proper governance structure for the alliance.

The joint R\&D activity to develop new STR drugs for AIDS involves extensive exchange of knowledge among both firms. Hence, each firm within the alliance contributes their knowledge-based resources. According to Das and Teng (2000) when both parties within the alliance possess knowledge-based resource, the proper structure is bilateral contract agreements. The agreement will determine the role such as who is in charge for formulation, manufacturing, registration and commercialization of the product and the detailed rights and obligation each party bears.

Johnson\&Johnson and Cipla would like to strengthen its foothold in AIDS sector. Therefore they need to exchange knowledge relevant to the sector. Johnson and Johnson needs Cipla local Indian network to be able to penetrate the Indian market to develop location-bound Firm Specific Advantage to reduce liability of foreignness (Verbeke, 2009). Simultaneously, Cipla would like to strengthen their capabilities in the firm market internationalisation and best practices 
in pharmaceutical industry. The specific knowledge possessed by both parties are form of knowledge-based resources hence the appropriate alliance structure is bilateral contract agreements (Das and Teng, 2000). The process of knowledge exchange might take form as reciprocal personnel training by each firm in accordance with the contracts established. The personnel exchange within both parties is also an important element. Delegation of one firm would be involved in particular activities relevant to the respective agreement in the counterparty firm. Hence the transfer of knowledge runs smooth with proper scope as determined in the contract.

\section{Potential Conflicts and Additional Considerations}

Defining expected conflicts can help Johnson and Johnson anticipate potential conflict to occur at later stage. Later conflict resolution would be very costly as things will be more complicated. Cultural differences, opportunistic behavior and unclear roles problems within the alliance as will be elaborated below.

Firstly, Although both firms possess similar corporate culture, the management styles and employees culture may be different as the $\mathrm{CEO}$ and almost all employees of Cipla is Indian. However, cultural differences is expected to exist in any alliances. The process to create alliance culture which accommodate both parties is crucial to be developed. With both Johnson \& Johnson and Cipla high social capital as it has been experienced in forming alliance can help to play-off the cultural difference.

Secondly, opportunistic behavior may also arise in both parties. High knowledge-based resources owned by both parties are very vulnerable as low level of IPR protection in
India provides more incentive to behave opportunistically. This is especially a diasadvantage for Johnson and Johnson as thay can be categorized more superior than Cipla in terms of knowledge based. Thus this issue should be addressed comprehensively. Lastly, unclear role problem within the alliance should be concerned since the it will lead to confusion of direction and champion within alliance. The structure of alliance should be defined clearly and communicated towards the personnels who is involved in alliance immediately as the alliance is started.

\section{Governance Model and Decision Making Approach}

Alliance often ends in disastrous result as Peter (2011) indicated that up to $70 \%$ alliances do not work. Therefore alliance mechanism should be established in order to ensure the successfulness of an alliance. Several things can be done suchs as:

- Establishing dedicated alliance team. The dedicated team is responsible to monitor and smoothen the alliance process. As stated by Kale et al (2002), firms with dedicated alliance team are mosre successful with the alliance. This also responds to the need of clear role and structure to the alliance. This team can also act as the culture assimilator so to minimize cultural differences.

- $\quad$ Limiting alliance scope. Li et al (2008) said that determining alliance scope can enhance the safeguards between alliance. As knowledge-based property is very vulnerable to opportunistic behavior, this step is extremely important to avoid excessive knowledge spillover. This activity is indirectly served by goal establishment to focus in 
R\&D collaboration of particular product and in management expertise of Cipla.

- Developing milestones for alliance. The alliance would be going for quite long time. Therefore a monitoring device is needed. Developing milestones with an agreed upon parameter could be a way to monitor the progress of the alliance. Performance of strategic alliances can be measured using product developments evaluation (Deeds\& Hill, 1996). This is particularly relevant for the goal number one where the collaboration is about developing a product. Targeting the progress i.e the time to go through phase I, II or III can be a way to evaluate the successfulness or the progress of the alliance. For the goal number two, the measurement tool could be how many contacts have emerged from the collaboration or to compare the efficiency level of Johnson\&Johnson with Cipla. Any deviation from target should be considered carefully by the dedicated alliance team. Corrective action should be take in response to the deviation to ensure the smoothnes of the alliance performance. By making safeguards mentioned above, the alliance between Johnson \& Johnson and Cipla is expected to run smoothly since expected conflicts have been anticipated.

\section{Johnson\&Johnson's Alliance Development: Creating Competitive Advantage}

Alliance provide a way for organizations to leverage resources and a smart way to grow (Sari, 2003). Alliance enable business to gain competitive advantage through access to a partner's resources, including markets, technologies, capital and people. Furthermore Kotelnikov (2001) stated that fast-growing companies rely heavily on alliances to extend their operational and technical resources. They use alliances to benefit from more-established channels of distribution, marketing, or brands reputation of bigger, better-known players.

Some reasons may be found to explain how the development of an alliance can create a competitive advantage. Sari (2003) stated that definite reasons attribute to this phenomenon are the financial pressures and the time constraints that have squeezed managers without the resources to fill the gaps through internal development. This phase can show manager's ability in dealing with changes and solving problems. In addition, the development of alliance should be in tune to maintain flexibility, core competence and the incentives that arise from autonomy, while utilizing complementary resources for both efficiency and learning (Freeman \& Perez: 1989). In J\&J, previous alliances success could be the best "teacher" to create a better way to develop their alliance with Cipla. To gain the market segment access, as stated on their alliance objective, the management of the alliance should build a strong tool in communication, control, and measurement system. With an integrated system covering those all, the alliance can develop in a proper way.

The Strategic alliance between Johnson \& Johnson and Cipla Pharmaceutical company can help them toughen the corporate development strategy. Because of their similarities in the production of antiinfectious drugs, they can cooperate to 
penetrate emerging markets and do several R\&D collaborations to develop new Hepatitis-C especially for other genotypes. As both firms have high knowledge resource in the field of Hepatitis C and TB, strengths of both firm can be combined such as joint $R \& D$ (which J\&J strength in the financial and Cipla in the R\&D) and share their facilities. Additionaly Cipla helps J\&J answers the demand in emerging market to make AIDS drugs more affordable. This can result in a strengthen competitive position for both partners. Therefore, strategic partnership between Johnson \& Jodnson and Cipla may overcome obstacles, for example the entrenched competition, hostile government regulations, and also cultural customs.

\section{Conclusion and Sugestion}

Johnson \& Johnson is an American multinational medical devices, pharmaceutical and consumer packaged goods manufacturing company. Its common stock is a component of the Dow Jones Industrial Average and the company is ranked No. 37 on the 2018 Fortune 500 list of the largest United States corporations by total revenue. The company's major franchises in the Pharmaceutical segment include Immunology, Neuroscience, Infectious Disease, and Oncology. Infectious diseases have caused an unprecedented global health crisis, Infectious diseases products include Incivio (telaprevir), a hepatitis C protease inhibitor; Intelence (Etravirine), a non-nucleoside HIV polymerase inhibitor; and Prezista (darunavir), an HIV protease inhibitor. Etravirine and darunavir are notable for their high barriers to resistance development.
For the future 10 years, the expansion strategy is still need to developed and improved. Developing countries are prosperous market for Johnson\&Johnson. Especially in Asia. Asia becomes a crucial part of its portfolio development in infectious and metabolic diseases. Therefore, open innovation through more research partnerships and collaborative efforts that connect the medical and academic communities to its $R \& D$ centers is needed by Johnson\&Johnson. Based on data in the research analysis, Cipla is the best choice for Johnson\&Johnson Alliance because Cipla made a low-cost anti AIDS drugs and also other medicine including for TB and Hepatitis for developing countries patients. Roughly 40 percent of HIV/AIDS patients undergoing antiretroviral therapy worldwide take Cipla drugs. In the established criteria, Cipla can helps Johnson\&Johnson to achieve its goals.

The joint R\&D activity between Johnson\&Johnson and Cipla Inc to develop new STR drugs for AIDS involves extensive exchange of knowledge among both firms. Each firm within the alliance contributes their knowledge-based resources, the proper structure is bilateral contract agreements. The agreement will determine the role such as who is in charge for formulation, manufacturing, registration and commercialization of the product and the detailed rights and obligation each party bears. Johnson \& Johnson and Cipla would like to strengthen its foothold in AIDS sector. Therefore they need to exchange knowledge relevant to the sector. Johnson \& Johnson needs Cipla local Indian network to be able to penetrate the Indian market to develop location-bound Firm Specific Advantage to reduce liability of foreignness (Verbeke, 
2009). Cipla expertise in low cost manufacturing helps Johnson and Johnson to achieve greater efficiency to answer the demand in emerging market and mission to make AIDS drugs more affordable. Furthermore, Cipla would like to strengthen their capabilities in the firm market internationalisation and best practices in pharmaceutical industry. The Strategic alliance between Johnson \& Johnson and Cipla Inc can help them toughen the corporate development strategy. Because of their similarities in the production of antiinfectious drugs, they can cooperate to penetrate emerging markets and do several $R \& D$ collaborations to create a competitive advantage especially in Asia market to help mankind to get the best medicine (anti infectious drugs) with affordable prices. In the future, we hope Johnson \& Johnson can develop cooperation with Cipla and other companies not only in anti-infectious drugs but also in other treatments so that they can make the best contribution to the world.

\section{References}

Aaker, David A. (2013). Manajemen Pemasaran Strategi. Edisi ke delapan. Salemba Empat. Jakarta. About.com. (2011). Culture: Your Environment for People at

Work.(http://humanresources.about.co $\mathrm{m} / \mathrm{od} /$ organizationalculture/a/culture.h tm. Retrieved November 8, 2018).

Advantage Business Media. (2009, June 12). J\&J Opens R\&D Center in Shanghai. (http://www.dddmag.com/news-JJ-

Opens-RD-Center-in-Shanghai-

061209.aspx America's Biotechnology
Research Companies. 2010. Medicines in Development for AIDS. Retrieved November 2, 2018, from Drug Discovery $\&$ Development).

Answer Corporation. (2017). Cipla Limited. (http://www.answers.com/topic/cipla.

Retrieved November 13, 2018).

Avert. (2011).

News.

(http://www.avert.org/new-aids-

drugs.htm. Retrieved November 5, 2018)

Bloomberg.

(2011).

News.

(http://www.bloomberg.com/news/201

1-05-23/j-j-aids-pill-signals-9-billion-in-

sales-to-ease-recall-woes.html. Retrieved

November 2, 2018).

Brackman, S., Garretsen, H., \& van Marrewijk, C. (2006). Cross Border Mergers \& Acquisitions: The Facts as a Guide for International Economics, CESifo Working Paper: CESifo.

Cartwright, S. \& Schoenberg, R. (2006). Thirty Years of Mergers and Acquisitions Research: Recent Advances and Future Opportunities. British Journal of Management, 17: 1-5.

Cipla. (n.d.). Code of conduct. (http://www.cipla.com/corporateprofile /code_of_conduct.htm. Retrieved November 8, 2011).

Cummings, Stevan R. Holmberg and Jeffrey L.(2009). Building Successful Strategic Alliances. Long Range Planning, 42(2): 164-193.

Das and Teng. (2000). A Resource-Based Theoryof Strategic Alliances. Journal of Management 2000, Vol. 26, No. 1, 3161.

Grant RM, Baden-Fuller C.(2004). A 
knowledge accessing theory of strategic alliances. Journal of Management Studies, 41:61-84

Hoffman and Schlosser. (2000). Success Factors of Strategic Alliances in Smalland Medium-sized Enterprises: An Empirical Survey. Long Range Planning.
Hospitalharma.2010. Corporate Information. Tibotec and JJ Cleared to Launch Aptivus Rival

(http://www.hospitalpharma.com/featur es/feature.asp?ROW_ID=847. Retrieved November,5, 2018)

Hoffmann, W.H. \& Schaper-Rinkel W. (2001). Acquire or Ally? -A strategy framework for deciding between acquisition and cooperation. Management International Review, 41: 131-159. 
Journal of Digital Marketing And Halal Industry

Vol. I, No. I (2019), 25-46

http://journal.walisongo.ac.id/index.php/JDMHI/index

$46 \mid \mathrm{P}$ a g e http://dx.doi.org/10.21580/jdmhi.2019.1.1.4730 